\title{
INTRAVENOUS IRON SUCROSE IN MALNOURISHED CHILDREN WITH IRON DEFICIENCY ANEMIA.
}

1. MBBS

Medical Officer

Children's Hospital \& ICH, Multan.

2. MBBS, FCPS (Paediatrics Medicine)

Associate Professor

The Children's Hospital \& ICH, Multan.

3. MBBS, FCPS (Paediatrics Medicine) Senior Registrar

Children's Hospital \& ICH, Multan.

Correspondence Address:

Dr. Fahd Nazir

Medical Officer

Children's Hospital \& ICH, Multan.

dr_fahad_nazir@yahoo.com

Article received on:

03/09/2019

Accepted for publication:

$25 / 01 / 2020$
Fahad Nazir ${ }^{1}$, Asim Khurshid ${ }^{2}$, Muhammad Abu Talib ${ }^{3}$

ABSTRACT... Objectives: To compare the mean hemoglobin level before and six weeks after giving intravenous iron sucrose therapy in malnourished children having iron deficiency anemia. Study Design: Quasi Experimental Study. Setting: Nutritional Stabilization Centre, Children Hospital and Institute of Child Health, Multan. Period: From July 2018 to December 2018. Material \& Methods: A total of 80 patients were enrolled in the study. Hemoglobin level at baseline was recorded. IV iron sucrose therapy was divided into 3 equal doses and administered on 3 consecutive days. After 6 weeks of administration of iron sucrose, hemoglobin level was noted. Independent sample T-test was applied to compare $\mathrm{Hb}$ level before and after therapy with p-value $\leq 0.05$ as significant. Results: Overall, mean age was $13.39 \pm 6.11$ months. There were $54(67.5 \%)$ males and $28(32.5 \%)$ females. The mean weight of patients was $5.06 \pm 1.45 \mathrm{~kg}$ and mean height was $64.59 \pm 8.72 \mathrm{~cm}$. The weight for height ratio was <-3SD in all patients $(100 \%)$. The mean hemoglobin level of patients at baseline was $7.37 \pm 0.44 \mathrm{~g} / \mathrm{dl}$, which was improved to $9.47 \pm 0.47 \mathrm{~g} / \mathrm{dl}$ after 6 weeks treatment. This was significant improvement $(p<0.05)$. Conclusion: Thus intravenous iron sucrose therapy can significantly improve the condition of child and rectify the IDA.

Key words: $\quad$ Baseline, Hemoglobin, Intravenous Iron Sucrose, Malnourished.

Article Citation: Nazir F, Khurshid A, Talib MA. Intravenous Iron Sucrose in Malnourished Children with Iron Deficiency Anemia. Professional Med J 2020; 27(9):18671871. DOI: 10.29309/TPMJ/2020.27.09.4107

\section{INTRODUCTION}

Childhood malnutrition is a multi-dimensional problem, responsible for significant morbidity and mortality amongst pediatric population. ${ }^{1,2}$ In developing countries, childhood malnutrition is more pronounced as $53 \%$ of child mortality per year is attributed to this. $\frac{3}{\text { Unfortunately, in terms }}$ of infant and child mortality, Pakistan is ranked $2^{\text {nd }}$ highest amongst South Asian Countries. Malnutrition contributes significantly to childhood morbidity as well mortality in our part of the world as well. 4

In children, protein energy malnutrition is most common and often associated with iron deficiency anemia (IDA). ${ }^{5,6}$ In developing countries, World health Organization (WHO) estimated $30 \%$ of the children from 0 to 4 years and $48 \%$ of 5 to 14 years having anemia. In Pakistan, frequency of IDA is noted as from $15-63 \%$ amongst children population. ${ }^{?}$
It is imperative that malnutrition and IDA should be diagnosed early and treated promptly. Oral iron therapy is generally well tolerated in most of the children but in many children the compliance is poor and not properly tolerated as they develop gastrointestinal (Gl) problems such as diarrhea, constipation and vomiting. Some children may even be unresponsive to oral iron therapy because of $\mathrm{Gl}$ dysfunction. A study conducted at Ben-Gurion University of the Negev, Israel showed Hemoglobin $(\mathrm{Hb})$ rise to $9.27 \pm 1.23 \mathrm{~g} /$ dl with intravenous (IV) iron sucrose therapy in children with IDA. ${ }^{8}$ A Pakistani study showed $\mathrm{Hb}$ rise to $9.21 \pm 1.13 \mathrm{~g} / \mathrm{dl}$ with IV iron sucrose therapy. ${ }^{9}$ Another Pakistani study conducted by lqbal et al., from $\mathrm{CMH}$ Quetta, Pakistan reported that parenteral iron sucrose therapy improved mean $\mathrm{Hb}$ level from $6.65 \pm 0.65 \mathrm{~g} / \mathrm{dl}$ to $10.35 \pm 1.17 \mathrm{~g} / \mathrm{dl}$ in malnourished children with IDA. They concluded that IV iron sucrose therapy in malnourished children with IDA is safe and efficient. ${ }^{10}$ 
The aim of this study is to compare the mean $\mathrm{Hb}$ level before and after IV iron sucrose therapy in malnourished children having IDA. Previous studies documented that IV iron sucrose therapy can help in improving $\mathrm{Hb}$ level to a variable extent. IDA seems quite common in our region and this study was aimed to provide useful evidence about the role of IV iron amongst anemic malnourished children in our setting.

\section{MATERIAL \& METHODS}

This was a quasi-experimental study, done at Nutritional Stabilization Centre, Department of Pediatric Medicine, Children Hospital and Institute of Child Health, Multan, from July 2018 to December 2018.

A total 80 cases, calculated with confidence level $=95 \%$, power of the test $=90 \%$ and taking magnitude of mean $\mathrm{Hb}$ level $6.65 \pm 0.65 \mathrm{~g} / \mathrm{dl}$ before and $10.35 \pm 1.17 \mathrm{~g} / \mathrm{dl}$ after parenteral iron sucrose therapy in malnourished children with IDA. ${ }^{10}$ Malnourished (weight for height/length $<-3 S D$ ) children of both genders, aged 6 months to 12 years, having IDA (hemoglobin level < $10 \mathrm{~g} / \mathrm{dl}$ and Serum Ferritin levels < $20 \mathrm{ng} / \mathrm{mL}$ ) were enrolled. Children having history of Iron supplementation therapy in past 6 months (on medical record), known for other causes of anemia like Thalassemia, sickle cell anemia, sideroblastic anemia, G6PD deficiency and hemolytic anemia (on medical record), having cerebral palsy, febrile seizures or epilepsy, were not included.

Approval was taken from Institutional Ethical Committee. Informed consent was obtained from parents after explaining them the risks and benefits of intravenous iron sucrose therapy. Demographic information (name, age, gender, weight and duration of disease) was noted. Then $\mathrm{Hb}$ level at baseline was noted from medical record.

Iron sucrose infusion is available as $5 \mathrm{ml}$ solution containing $100 \mathrm{mg}$ of iron. Dose was calculated by following formula; ${ }^{9}$

$\frac{\text { NormalHb for age Initial } \mathrm{Hb}}{100} \times$ Blood volume $(\mathrm{ml}) \times 3.4 \times 1.5$
- 3.4 is a constant that converted grams of Hemoglobin into milligrams of iron.

- 1.5 is a constant that gave extra iron to replace the stores.

- Blood volume was $80 \mathrm{ml} / \mathrm{kg}$.

Total dose was divided into 3 equal doses and administered on 3 consecutive days. Each single dose was diluted in $100 \mathrm{ml} 0.9 \%$ normal saline and given IV over a period of 2-3 hours with monitoring of vitals and any sign of adverse reaction. Then after 6 weeks of administration of iron sucrose, hemoglobin level was assessed by taking blood sample under aseptic measures and was sent to the laboratory of the hospital. Report was assessed and $\mathrm{Hb}$ level was noted. All the information was entered for final analysis in predesigned proforma (attached).

Data was entered and analyzed using SPSS-20. Mean and SD were calculated for the age, weight of child, duration of disease and $\mathrm{Hb}$ level before and after intravenous iron sucrose therapy. Frequency and percentage were calculated for gender. Paired t-test was applied to compare $\mathrm{Hb}$ level before and after therapy with $p$-value $\leq 0.05$ as significant. Effect modifiers like age, gender, weight for height (\%) and duration of disease were controlled through stratification. Post stratification, independent t-test was applied taking $p$ value less than or equal to 0.05 as significant.

\section{RESULT}

The mean age of patients was $13.39 \pm 6.11$ months. There were 54 (67.5\%) males and 28 (32.5\%) females. The mean weight of patients was $5.06 \pm 1.45 \mathrm{~kg}$ and mean height was $64.59 \pm 8.72 \mathrm{~cm}$. The weight for height ratio was $<-3 S D$ in all patients (100\%).

The mean duration of disease was $5.69 \pm 2.37$ months. The mean hemoglobin level of patients at baseline was $7.37 \pm 0.44 \mathrm{~g} / \mathrm{dl}$, which was improved to $9.47 \pm 0.47 \mathrm{~g} / \mathrm{dl}$ after 6 weeks treatment. This was significant improvement $(p<0.001)$.

Table-I shows data stratification for age of patients. In patients aged 6-12months, the 
mean hemoglobin level of patients at baseline was $7.40 \pm 0.37 \mathrm{~g} / \mathrm{dl}$, which was improved to $9.41 \pm 0.42 \mathrm{~g} / \mathrm{dl}$ after 6 weeks treatment. This was significant improvement $(p<0.001)$. In patients aged 13-24months, the mean hemoglobin level of patients at baseline was $7.32 \pm 0.53 \mathrm{~g} / \mathrm{dl}$, which was improved to $9.56 \pm 0.53 \mathrm{~g} / \mathrm{dl}$ after 6 weeks treatment. This was significant improvement $(p<0.001)$.

Table-Il shows data stratification for gender of patients. In male patients, the mean hemoglobin level of patients at baseline was $7.35 \pm 0.39 \mathrm{~g} /$ $\mathrm{dl}$, which was improved to $9.42 \pm 0.45 \mathrm{~g} / \mathrm{dl}$ after 6 weeks treatment. This was significant improvement $(p<0.001)$. In female patients, the mean hemoglobin level of patients at baseline was $7.41 \pm 0.54 \mathrm{~g} / \mathrm{dl}$, which was improved to $9.59 \pm 0.51 \mathrm{~g} / \mathrm{dl}$ after 6 weeks treatment. This was significant improvement $(p<0.001)$.

Table-III shows data stratification for duration of disease. In patients having disease from $3-6$ months, the mean hemoglobin level of patients at baseline was $7.43 \pm 0.40 \mathrm{~g} / \mathrm{dl}$, which was improved to $9.49 \pm 0.47 \mathrm{~g} / \mathrm{dl}$ after 6 weeks treatment. This was significant improvement $(p<0.001)$. Inpatients having disease from 7-11, the mean hemoglobin level of patients at baseline was $7.16 \pm 0.53 \mathrm{~g} / \mathrm{dl}$, which was improved to $9.40 \pm 0.51 \mathrm{~g} / \mathrm{dl}$ after 6 weeks treatment. This was significant improvement $(p<0.001)$.

\begin{tabular}{|c|c|c|c|c|}
\hline \multicolumn{2}{|c|}{ Age (Months) } & Baseline & After 6 & P-Value \\
\hline \multirow{3}{*}{$6-12$} & $n$ & 46 & 46 & \multirow{3}{*}{$<0.001$} \\
\hline & Mean & 7.40 & 9.41 & \\
\hline & SD & 0.37 & 0.42 & \\
\hline \multirow{3}{*}{$13-24$} & $\mathrm{n}$ & 34 & 34 & \multirow{3}{*}{$<0.001$} \\
\hline & Mean & 7.32 & 9.56 & \\
\hline & SD & 0.53 & 0.53 & \\
\hline & $\begin{array}{l}\text { oglo } \\
\text { oglo }\end{array}$ & $\begin{array}{l}\text { of pre } \\
\text { vel str }\end{array}$ & $\begin{array}{l}\text { post } \\
\text { for }\end{array}$ & ment \\
\hline
\end{tabular}

\begin{tabular}{|c|c|c|c|c|}
\hline \multicolumn{2}{|c|}{ Gender } & Baseline & $\begin{array}{l}\text { After } 6 \\
\text { Weeks }\end{array}$ & P-Value \\
\hline \multirow{3}{*}{ Male } & $\mathrm{n}$ & 54 & 54 & \multirow{3}{*}{$<0.001$} \\
\hline & Mean & 7.35 & 9.42 & \\
\hline & SD & 0.39 & 0.45 & \\
\hline \multirow{3}{*}{ Female } & $\mathrm{n}$ & 26 & 26 & \multirow{3}{*}{$<0.000$} \\
\hline & Mean & 7.41 & 9.59 & \\
\hline & SD & 0.54 & 0.51 & \\
\hline
\end{tabular}

Table-II. Comparison of pre and post treatment hemoglobin level stratified for gender.

\begin{tabular}{|c|c|c|c|c|}
\hline \multicolumn{2}{|c|}{ Duration (Months) } & \multirow{2}{*}{$\begin{array}{c}\text { Baseline } \\
63\end{array}$} & \multirow{2}{*}{$\begin{array}{c}\text { After } 6 \\
\text { Weeks } \\
63\end{array}$} & \multirow[t]{2}{*}{ P-Value } \\
\hline \multirow{3}{*}{$3-6$} & $\mathrm{~N}$ & & & \\
\hline & Mean & 7.43 & 9.49 & \multirow[t]{2}{*}{$<0.001$} \\
\hline & SD & 0.40 & 0.47 & \\
\hline \multirow{3}{*}{$7-11$} & $\mathrm{~N}$ & 17 & 17 & \multirow{3}{*}{$<0.001$} \\
\hline & Mean & 7.16 & 9.40 & \\
\hline & SD & 0.53 & 0.51 & \\
\hline
\end{tabular}

Table-III. Comparison of pre and post treatment hemoglobin level stratified for duration of disease.

\section{DISCUSSION}

Protein energy malnutrition, iron deficiency and anemia, vitamin A deficiency and iodine deficiency disorders are the 4 major forms of malnutrition globally. ${ }^{11}$ We noted the mean hemoglobin level of children at baseline as $7.37 \pm 0.44 \mathrm{~g} / \mathrm{dl}$, which was improved to $9.47 \pm 0.47 \mathrm{~g} / \mathrm{dl}$ after 6 weeks treatment. This was significant improvement $(p<0.05)$. In another study amongst children with IDA, it was noted that $\mathrm{Hb}$ was raised to $9.27 \pm 1.23 \mathrm{~g} / \mathrm{dl}$ with IV iron sucrose therapy. ${ }^{8}$ One Pakistani study showed $\mathrm{Hb}$ rise to $9.21 \pm 1.13 \mathrm{~g} /$ dl with IV iron sucrose therapy. ${ }^{9}$ These studies although show increase in $\mathrm{Hb}$ but that falls in anemic level.

In children, IDA is quite common in our part of the world but not much data evaluating IV iron sucrose infusion exist in our part of the world. Rise in hemoglobin of 3.9 and $2.2 \mathrm{~g} / \mathrm{dl}$ was reported previously. ${ }^{12}$ Pinsk $V$ et al evaluated the safety as well as efficacy of iron sucrose amongst children with IDA and noted a significant rise, very consistent with our findings. ${ }^{13}$ Our findings are also consistent with those of Crary SE et al, where they found median $\mathrm{Hb}$ rise of $2-3 \mathrm{~g} / \mathrm{dl} .{ }^{14}$ 
We noted minor adverse reactions in the present study. Schroder $\mathrm{O}$ et al, noted 2 main adverse events during their study but IV iron sucrose therapy continued even after those events. ${ }^{15}$ Theusinger OM noted mean hemoglobin increase of $1 \pm 0.6 \mathrm{~g} / \mathrm{dl}$ after 2 weeks of IV iron sucrose use in cases waiting to get operated. ${ }^{16}$

One Pakistani study conducted by lqbal et al., from $\mathrm{CMH}$ Quetta, Pakistan reported that parenteral iron sucrose therapy improved $\mathrm{Hb}$ to $10.53 \pm 1.17 \mathrm{~g} / \mathrm{dl}$ which falls in normal $\mathrm{Hb}$ level $(>10 \mathrm{~g} / \mathrm{l})$. They concluded that intravenous iron sucrose therapy in malnourished children with IDA is safe and efficient. ${ }^{10}$

In France, Bayomeu $\mathrm{F}$ and colleagues noted superior increase in hemoglobin ( $p$ value $<0.001$ ) with the use of IV iron sucrose in comparison to oral iron. ${ }^{17}$ They found that hemoglobin was raised from $9.6 \mathrm{~g} / \mathrm{dl}$ to $11.11 \mathrm{~g} / \mathrm{dl}$ in 4 weeks of treatment. These findings are similar to what we discovered. Regarding the use of IV iron sucrose. A study from Agha Khan Hospital Karachi was done to compare the efficacy of IV iron sucrose with iron sorbitol and they noted good increase of $2.6 \mathrm{~g} / \mathrm{dl} \mathrm{Hb}$ amongst IV iron sucrose patients. ${ }^{18}$

\section{CONCLUSION}

Thus intravenous iron sucrose therapy can significantly improve the condition of child and rectify the IDA. We followed-up patients till 6 weeks for study purpose but we recommend further trials with prolonged follow-ups in order to rectify the IDA completely and achieve normal hemoglobin level.

Copyright@ 25 Jan, 2020.

\section{REFERENCES}

1. Tette EM, Sifah EK, Nartey ET. Factors affecting malnutrition in children and the uptake of interventions to prevent the condition. BMC Pediatr 2015; 15(1):1.

2. Wong HJ, Moy FM, Nair S. Risk factors of malnutrition among preschool children in Terengganu, Malaysia: A case control study. BMC Pub Health 2014; 14(1):1.
3. Rukundo GZ, Beinempaka F, Ntaro M, LeBlanc JC. Maternal depression and malnutrition in children in southwest Uganda: A case control study. BMC Pub Health 2015; 15(1):1.

4. Hirani SAA. Malnutrition in young Pakistani children. J Ayub Med Coll 2012; 24(2):150.

5. Samin I, Moorani K. Morbidity patterns of severely malnourished children at a tertiary care hospital. Pak Ped J 2014; 38(1):3-8.

6. Moshe G, Amitai Y, Korchia G, Korchia L, Tenenbaum A, Rosenblum J, et al. Anemia and iron deficiency in children: Association with red meat and poultry consumption. J Pediatr Gastroenterol Nutr 2013; 57(6):722-7.

7. Özdemir N. Iron deficiency anemia from diagnosis to treatment in children. Turk Arch Pediatr 2015; 50(1):11.

8. Pinsk V, Levy J, Moser A, Yerushalmi B, Kapelushnik $J$. Efficacy and safety of intravenous iron sucrose therapy in a group of children with iron deficiency anemia. Isr Med Assoc J 2008; 10(5):335-8.

9. Sheikh MA, Rabbani MW, Fozia AA, Iqbal I. Efficacy of intravenous iron sucrose infusion in children with iron deficiency anemia: Experience at children hospital \& ICH Multan. Med Forum 2015; 26(1):62-5.

10. Iqbal $M$, Malik $B$. Parenteral iron therapy in malnourished children. Pak Armed Forces Med J 2006; 56:271-5.

11. 99. Stephenson LS, Latham MC, Ottesen EA. Global malnutrition. Parasitology 2000; 121 Suppl:S5-22.

12. Shimada A. Adverse reactions to total-dose infusion of iron dextran. Clinical pharmacy 1982; 1(3):248.

13. Pinsk V, Levy J, Moser A, Yerushalmi B, Kapelushnik $J$. Efficacy and safety of intravenous iron sucrose therapy in a group of children with iron deficiency anemia. Blood 2008; 1050(3.4):1.5.

14. Crary SE, Hall K, Buchanan GR. Intravenous iron sucrose for children with iron deficiency failing to respond to oral iron therapy. Pediatric blood \& cancer 2011; 56(4):615-9.

15. Schröder O, Schrott M, Blumenstein I, Jahnel J, Dignass A, Stein J. A study for the evaluation of safety and tolerability of intravenous high-dose iron sucrose in patients with iron deficiency anemia due to gastrointestinal bleeding. Zeitschrift für Gastroenterologie 2004; 42(08):663-7. 
16. Theusinger OM, Schanz U, Spahn DR. Efficacy of intravenous iron sucrose administration for correcting preoperative anemia in patients scheduled for major orthopedic surgery. The Journal of the American Society of Anesthesiologists 2008; 109(1):152-.

17. Bayoumeu F, Subiran-Buisset C, Baka N-E, Legagneur $\mathrm{H}$, Monnier-Barbarino P, Laxenaire MC. Iron therapy in iron deficiency anemia in pregnancy: Intravenous route versus oral route. European Journal of Obstetrics \& Gynecology and Reproductive Biology 2005; 123:S15-S9.
18. Wali A, Mushtaq A. Comparative study--efficacy, safety and compliance of intravenous iron sucrose and intramuscular iron sorbitol in iron deficiency anemia of pregnancy. JPMA 2002; 52(9):392-5.

\begin{tabular}{|c|l|l|l|}
\hline \multicolumn{3}{|c|}{ AUTHORSHIP AND CONTRIBUTION DECLARATION } \\
\hline Sr. \# & \multicolumn{1}{|c|}{ Author(s) Full Name } & \multicolumn{1}{|c|}{ Contribution to the paper } & Author(s) Signature \\
\hline 1 & Fahad Nazir & $\begin{array}{l}\text { Data collection, Drafting, Data } \\
\text { analysis. } \\
\text { Idea, Methodology, Literature } \\
2\end{array}$ & $\begin{array}{l}\text { Asim Khurshid } \\
\text { Review, Proof reading. }\end{array}$ \\
\hline 3 & Muhammad Abu Talib & Data collection, Discussion. \\
\hline
\end{tabular}

